\title{
KARAKTERISTIK PENDERITA TUBERKULOSIS DI RS IBNU SINA PERIODE JANUARI - DESEMBER 2017
}

\author{
Rachmat Faisal Syamsu' ${ }^{1}$, Fitriani ${ }^{2}$, Sri Zakiah Usman ${ }^{3}$, Freska ${ }^{4}$, Rihlah Thahirah Alhikmah ${ }^{4}$ \\ Fakultas Kedokteran Universitas Muslim Indonesia \\ Jl.Urip Sumohardjo No.5 KM.5,Kampus II UMI,Makassar. \\ ${ }^{1}$ Dosen Bagian IKM-IKK, Fakultas Kedokteran UMI \\ ${ }^{2}$ Dosen Pembimbing Klinik Puskesmas Maccini Sawah, Fakultas Kedokteran UMI \\ ${ }^{3}$ Dosen Pembimbing Klinik Puskesmas Tamangapa, Fakultas Kedokteran UMI \\ ${ }^{4}$ Mahasiswa Program Profesi Dokter, Fakultas Kedokteran UMI
}

\begin{abstract}
Abstrak
Tuberkulosis merupakan penyakit yang disebabkan oleh Mycobacterium tuberculosis. Bakteri patogen ini menyerang paru-paru dan organ tubuh lainnya.. Angka kejadian TB di Indonesia menempati urutan ketiga terbanyak di dunia setelah India dan Cina. Diperkirakan setiap tahun terdapat 528.000 kasus TB baru dengan kematian sekitar 91.000 orang. Tujuan penelitian ini adalah untuk mengetahui gambaran karakteristik penderita Tuberkulosis RS Ibnu Sina periode Januari-Desember 2017.Penelitian ini merupakan penelitian deskriptif dengan menggunakan pendekatan observasional dengan melihat data sekunder dari rekam medik RS Ibnu Sina. Jumlah populasi adalah 53 pasien, pengambilan sampel menggunakan metode total sampling. Penelitian dilakukan pada bulan Januari 2020 di RS.Ibnu Sina. Data dianalisa secara elektronik menggunakan perangkat lunak komputer program Microsoft Excel 2016 dengan tampilan deskriptif dan disajikan dalam bentuk tabel. Didapatkan Penderita Tuberculosis laki-laki (67,92\%) dan perempuan (32,07\%). Dari segi IMT didapatkan penderita underweight $(66,03 \%)$, normal (32,07\%), overweight (1,88\%). Dari kategori umur 1-25 tahun (20,75\%), 26-50 (32,07\%), dan $>50$ tahun (47,16\%). Berdasarkan kelompok pekerjaan didapatkan karyawan swasta $(13,20 \%)$, wiraswasta $(9,43 \%)$, buruh $(15,09 \%)$, IRT $(18,86 \%)$, mahasiswa $(7,54 \%)$, PNS $(7,54 \%)$, pedagang $(3,77 \%)$, TNI $(1,88 \%)$, pensiunan $(3.77 \%)$ dan yang tidak bekerja $(18.86 \%)$. Kriteria penderita Tuberculosis dari penelitian ini didapatkan dari jenis kelamin menunjukkan laki-laki lebih banyak dari perempuan, dari segi umur paling banyak pada usia $>50$ tahun, dari IMT paling banyak penderita Tuberculosis yang underweight, dan dari pekerjaan lebih banyak diderita oleh ibu rumah tangga dan yang tidak bekerja.
\end{abstract}

Kata Kunci: Tuberculosis, Jenis Kelamin, Indeks Massa Tubuh, Umur, Pekerjaan

\begin{abstract}
Tuberculosis is a disease caused by Mycobacterium tuberculosis. These pathogenic bacteria attack the lungs and other body organs. The TB incidence rate in Indonesia determines the third highest in the world after India and China. Estimated every year an estimated 528,000 new TB cases with approximately 91,000 deaths. The purpose of this study was to study the characteristics of tuberculosis sufferers in Ibnu Sina Hospital in the period JanuaryDecember 2017. This research examines research using observational research by looking at secondary data from the medical records of Ibnu Sina Hospital. The population was 53 patients, taking a sample using the total sampling method. The study was conducted in January 2020 at Ibnu Sina Hospital. Data were analyzed electronically using Microsoft Excel 2016 computer software with a descriptive display and presented in tabular form. Patients with Tuberculosis were obtained (67.92\%) and women (32.07\%). In terms of BMI obtained underweight sufferers $(66.03 \%)$, normal $(32.07 \%)$, overweight $(1.88 \%)$. Of the age categories $1-25$ years $(20.75 \%), 26-50(32.07 \%)$, and $>50$ years $(47.16 \%)$. Based on the occupational groups obtained by private employees $(13.20 \%)$, self-employed $(9.43 \%)$, laborers $(15.09 \%)$, IRT $(18.86 \%)$, students $(7.54 \%)$, civil servants $(7,54) \%)$, traders $(3.77 \%)$, TNI $(1.88 \%)$, retirees $(3.77 \%)$ and unemployed $(18.86 \%)$. The criteria for tuberculosis sufferers from this study came from gender. The scales of males were more than females, in terms of age at most at age $>50$ years, from IMT the most tuberculosis patients were thin, and from work suffered more by housewives and that doesn't work.
\end{abstract}

Keywords: Tuberculosis, Gender, Body Mass Index, Age, Work 


\section{Pendahuluan}

Penyakit tuberkulosis (TB) paru masih merupakan masalah utama kesehatan yang dapat menimbulkan kesakitan (morbiditas) dan kematian (mortalitas). ${ }^{1} \quad$ Diperkirakan sekitar sepertiga penduduk dunia telah terinfeksi oleh Mycobacterium tuberculosis. Pada tahun 1995, diperkirakan ada 9 juta pasien TB baru dan 3 juta kematian akibat TB di seluruh dunia. ${ }^{2}$

Tuberkulosis merupakan penyakit yang disebabkan oleh Mycobacterium tuberculosis dan varian mycobacterium lainnya seperti M. tuberculosis, M. africanum, M. bovis, M. canettii, dan M. microti. Bakteri patogen ini menyerang paru-paru dan organ tubuh lainnya. Mycobacterium tuberculosis umumnya disebarkan melalui udara dalam bentuk droplet nuklei yang menimbulkan respon granuloma dan inflamasi jaringan. Tanpa penanganan yang baik, kasus akan menjadi fatal dalam 5 tahun. ${ }^{3,4}$

Tuberkulosis sebenarnya dapat menyerupai penyakit paru lainnya seperti penumonia, penyakit paru interstitial bahkan keganasan akan tetapi dengan anamnesis yang baik, tuberkulosis dapat dengan mudah di tegakkan. Pada dasarnya pasien dengan sistem imun yang baik biasanya terserang tuberkulosis hanya pada satu area saja misalnya pada paru atau salah satu organ ekstra paru sedangkan pada pasien dengan immunokompeten, tuberkulosis dapat terjadi lebih daripada satu organ. ${ }^{3,4}$

Angka kejadian TB di Indonesia menempati urutan ketiga terbanyak di dunia setelah India dan Cina. Diperkirakan setiap tahun terdapat 528.000 kasus TB baru dengan kematian sekitar 91.000 orang. Prevalensi TB di Indonesia pada tahun 2009 adalah 100 per 100.000 penduduk dan TB terjadi pada lebih dari 70\% usia produktif (15-50 tahun). ${ }^{5}$ Angka ini akan terus bertambah apabila tidak diimbangi dengan edukasi dan terapi tuberkulosis yang adekuat. Oleh karena itu, hal ini lah yang membuat penulis tertarik melakukan penelitian untuk mengetahui bagaimana karakteristik pada penderita Tuberkulosis di RS Ibnu Sina periode Januari-Desember 2017.5,6 Diharapkan penelitian ini nantinya dapat menjadi acuan bagi masyarakat hingga pemerintah dalam menekan angka kejadian penyakit TB berdasarkan karakteristiknya.

\section{Bahan dan Metode}

Penelitian ini merupakan studi deskriptif dengan pendekatan observasional untuk melihat gambaran karakteristik penderita Tuberkulosis di RS Ibnu Sina periode Januari-Desember 2017. 
Populasi penelitian adalah penderita Tuberkulosis di RS Ibnu Sina periode Januari-Desember 2017. Pengambilan sampel menggunakan teknik total sampling, sehingga didapatkan sampel yang memenuhi kriteria sebesar 53 pasien.

Data yang digunakan adalah data sekunder dari rekam medik (untuk umur, pekerjaan, tinggi badan dan berat badan).

Proses pengolahan data secara elekronik dengan menggunakan perangkat lunak komputer program Microsoft Excel 2016 untuk analisis univariat agar diperoleh gambaran karakteristik penderita tuberkulosis paru di RS Ibnu Sina periode Januari-Desember 2017.

\section{Hasil Penelitian}

Karakteristik sampel berikut ini menjelaskan mengenai distribusi frekuensi dari setiap variabel terkait menenai jenis kelamin, umur, IMT dan pekerjaan pasien Tuberkulosis di RS Ibnu Sina periode Januari - Desember 2017. Adapun hasil analisis data tersebut sebagai berikut:

Berdasarkan jenis kelamin dapat diketahui bahwa jumlah pasien laki-laki dengan Tuberkulosis yaitu berjumlah 36 orang $(67,92 \%)$ dan jumlah pasien perempuan dengan Tuberkulosis yaitu berjumlah 17 orang (32,07\%).

Berdasarkan IMT dapat diketahui bahwa jumlah pasien Tuberkulosis dengan
IMT yang underweight sebanyak 35 orang $(66,03 \%)$, normal sebanyak 17 orang $(32,07 \%)$, overweight sebanyak 1 orang $(1,88 \%)$, obesitas I dan obesitas II sebanyak 0 orang $(0 \%)$.

Berdasarkan kelompok umur dapat diketahui bahwa jumlah pasien Tuberkulosis pada kelompok umur 1-25 tahun sebanyak 11 orang (20,75\%), 26-50 tahun sebanyak 17 orang $(32,07 \%),>50$ tahun sebanyak 25 orang $(47,16 \%)$.

Berdasarkan pekerjaan dapat diketahui bahwa jumlah pasien Tuberkulosis dengan pekerjaan karyawan swasta sebanyak 7 orang $(13,20 \%)$, wiraswasta sebanyak 5 orang $(9,43 \%)$, buruh sebanyak 8 orang $(15,09 \%)$, IRT sebanyak 10 orang $(18,86 \%)$, mahasiswa sebanyak 4 orang (7,54\%), PNS sebanyak 4 orang $(7,54 \%)$, TNI sebanyak 1 orang $(1,88 \%)$, pedagang sebanyak 2 orang $(3,77 \%)$, pensiunan sebanyak 2 orang (3.77\%), dan yang tidak bekerja sebanyak 10 orang $(18,86 \%)$.

\section{Pembahasan}

Berdasarkan jenis kelamin dapat diketahui bahwa jumlah pasien laki-laki dengan Tuberkulosis yaitu berjumlah 36 orang $(67,92 \%)$ dan jumlah pasien perempuan dengan Tuberkulosis yaitu berjumlah 17 orang (32,07\%). Hasil penelitian tersebut sesuai dengan laporan 
Department of Gender and Women's Health World Health Organization (WHO) yang menyatakan bahwa insiden dan prevalensi tuberkulosis lebih banyak ditemukan pada jenis kelamin laki-laki dari pada perempuan. ${ }^{7}$ Dan secara global ada lebih dari 70\% laki-laki dengan BTA positif dibandingkan dengan wanita. $^{8}$ Menurut R.E. Watkins dan A.J. Plant hal ini disebabkan karena kebiasaaan merokok pada laki-laki. Merokok telah diidentifikasi sebagai salah satu dari sejumlah variabel yang mungkin terkait dalam risiko angka kejadian tuberkulosis menurut jenis kelamin di dunia. Di banyak negara yang memiliki prevalensi tuberkulosis paru yang tinggi perokok didominasi oleh laki-laki. Penelitian ini menyimpulkan bahwa merokok merupakan salah satu faktor risiko yang dapat diubah (modified). ${ }^{8}$

Berdasarkan IMT, pasien Tuberkulosis dengan status gizi underweight lebih banyak ditemukan, yaitu sekitar 35 orang $(66,03 \%)$, dibandingkan gizi normal sebanyak 17 orang $(32,07 \%)$, dan overweight sebanyak 1 orang $(1,88 \%)$. Hal ini sejalan dengan penelitian yang dilakukan oleh Dodor di Ghana pada 570 pasien tuberkulosis paru dewasa menunjukkan rata- rata indeks massa tubuh pasien pada saat awal diagnosis adalah $18,3 \mathrm{~kg} / \mathrm{m} 2$ dan setelah menjalani pengobatan intensif selama dua bulan ratarata indeks massa tubuh pasien meningkat menjadi $19,5 \mathrm{~kg} / \mathrm{m} 2$. Dimana pada akhir fase intensif pengobatan $60 \%$ dari pasien memiliki status gizi normal. ${ }^{9}$ Penelitian yang dilakukan Schwenk dkk pada pasien tuberkulosis dewasa menyimpulkan bahwa pasien yang pulih dari infeksi tuberkulosis akan mencapai keseimbangan energi yang positif dan mengalami peningkatan berat badan. Hal ini disebabkan karena proses inflamasi yang terjadi pada penderita tuberkulosis menyebabkan penurunan massa lemak tubuh, dan mempengaruhi hormon leptin, yang merupakan hormon regulasi nafsu makan, serta berat badan. Sehingga penderita tuberkulosis mengalami penurunan berat badan yang drastis. ${ }^{10}$

Berdasarkan kelompok umur, pasien Tuberkulosis paling banyak ditemukan pada kelompok umur $>50$ tahun sebanyak 25 orang $(47,16 \%)$, diikuti oleh kelompok umur 26-50 tahun sebanyak 17 orang (32,07\%) dan kelompok umur 1-25 tahun sebanyak 11 orang (20,75\%). Hal ini sesuai dengan penelitian oleh Akbar dkk, mengenai penurunan fungsi imunitas pada orang tua. Pada orang tua terjadi penurunan fungsi innate dan cell mediated immunity, sehingga orang tua lebih rentan akan terkena infeksi. ${ }^{11}$

Berdasarkan pekerjaan dan sosial ekonomi, didapatkan penderita tuberkulosis yang terbanyak ialah ibu rumah tangga dan yang tidak bekerja 
dengan jumlah yang sama sebanyak 10 orang $(18,86 \%)$, diikuti dengan buruh sebanyak 8 orang $(15,09 \%)$, diikuti dengan karyawan swasta sebanyak 7 orang $(13,20 \%)$, diikuti dengan wiraswasta sebanyak 5 orang $(9,43 \%)$, diikuti dengan mahasiswa dan PNS yang memiliki jumlah yang sama sebanyak 4 orang $(7,54 \%)$, diikuti dengan pedagan dan pensiunan yang memiliki jumlah yang sama sebanyak 2 orang $(3,77 \%)$. Posisi terakhir ditempati oleh TNI, yaitu sebanyak 1 orang $(1,88 \%)$. Tuberkulosis sangat erat hubungannya dengan masyarakat yang memiliki social ekonomi rendah, karena pada orang yang social ekonomi rendah tinggal di pemukiman padat penduduk, ventilasi yang kurang bagus, minimnya pengetahuan akan kesehatan dan sanitasi, serta orang dengan sosial ekonomi rendah memiliki asupan gizi yang kurang, sehingga menjadi rentan terkena penyakit infeksi, seperti tuberkulosis. Menurut laporan WHO tahun 2003 sebanyak 90\% pasien tuberkulosis di dunia menginfeksi kelompok dengan sosial ekonomi lemah atau miskin. Hubungan antara kemiskinan dengan tuberkulosis bersifat timbal balik, penyakit tuberkulosis merupakan penyebab kemiskinan dan karena kemiskinan maka manusia menderita tuberkulosis. ${ }^{12}$

\section{Keterbatasan Penelitian}

Dalam penelitian ini instrumen pengumpulan data yang digunakan adalah data sekunder dari rekam medik. Pada penelitian ini terdapat keterbatasan penelitian yang didapatkan, yaitu:

a. Masa perawatan yang berbeda pada masing-masing pasien dikarenakan oleh beberapa faktor, seperti penyakit penyerta pada pasien akan memberikan pengaruh pada frekuensi pemberian terapi yang menjadi penentu efektifitas dari terapi itu sendiri.

b. Faktor - faktor lain yang berada diluar kendali peneliti, seperti riwayat berobat sebelumnya, asupan makanan seharihari. dll.

\section{Kesimpulan}

Karakteristik jenis kelamin pada penderita Tuberkulosis didapatkan jumlah pasien laki-laki lebih banyak dibandingkan pasien perempuan.

Karakteristik umur pada penderita Tuberkulosis didapatkan jumlah pasien berumur lansia (>50 tahun) lebih banyak dibandingkan pasien dengan usia produktif.

Karakteristik IMT pada penderita Tuberkulosis didapatkan jumlah pasien dengan status gizi underweight paling banyak dibandingkan status gizi yang lainnya. 
Karakteristik pekerjaan pada penderita Tuberkulosis didapatkan jumlah pasien dengan status pekerjaan ibu rumah tangga dan diikuti dengan yang tidak bekerja dibandingkan dengan pekerjaan lain.

\section{Saran}

Untuk peneliti lain, yang akan menggunakan topik yang sama, disarankan untuk lebih menganalisis lamanya masa perawatan pada pasien dengan tuberculosis serta riwayat minum obat sebelumnya, agar dapat memperoleh hasil lebih maksimal.

\section{Daftar Pustaka}

1. Aditama, TY,. Chairil, AS,. 2002. Jurnal Tuberkulosis Indonesia. Jakarta : Perkumpulan Pemberantasan Tuberkulosis Indonesia.

2. Departemen Kesehatan Republik Indonesia. 2006. Pedoman Nasional Penanggulangan Tuberkulosis Edisi 2 Cetakan Pertama. Jakarta.

3. Fauci, Anthony S. Kasper, Dennis L. Longo, Dan L. Braunwald, Hauser, Eugene Stephen L. Jameson, J. Larry. Loscalzo, Joseph. Chapter 158 Tuberculosis in: Harrison principle of internal medicine 17 th edition. USA: Mc Graw Hill. 2008

4. Iseman, Michael D. Chapter 345 Tuberculosis in: Goldman, Lee.
Ausiello, Dennis. Cecil medicine 23rd edition. Philadelphia: Elsevier Saunders. 2008.

5. World Health Organization. 2010. Epidemiologi tuberkulosis di Indonesia. Diakses pada 17 November 2019 pukul 14:39 WIB http://www.tbindonesia.or.id/tbnew/ep idemiologi-tb-diindonesia/article/55/000100150017/2

6. World Health Organization. World Global Tuberculosis Control 2011. Geneva World Health Organization. 2011

7. Rokhmah D. Gender dan penyakit tuberkulosis. Implikasinya terhadap akses layanan masyarakat miskin yang rendah. Jurnal Kesehatan Masyarakat Nasional. 2013; vol.9(10).

8. Watkins RE, Plant AJ. Does smoking explain sex differences in the global tuberculosis epidemic? Epidemiol, Infect 2006; 134:333-339.

9. Dodor A. Evaluation of nutritional status of new tuberculosis patients at the Effia-Nkwanta regional hospital. Ghana Medical Journal. 2008 Vol.42. No1.

10. Schwenk A, Hodgson I, Wright A, et al. Nutrient partitioning during treatment of tuberculosis: gain in body fat mass but not in protein mass. Am J Clin Nutr 2004;79:1006-12. 
11. Akbar AN, Henson SM. Are senescence and exhaustion intertwined or unrelated processes that compromise immunity? Nat Rev Immunol. 2011; 11(4):289-95.

12. Rukmini, Chatarina UW. Faktorfaktor yang berpengaruh terhadap kejadian TB paru dewasa di Indonesia (analisis data riset kesehatan dasar tahun 2010). Buletin Penelitian Sistem Kesehatan. Surabaya; 2011. vol. 14: $320-331$. 
Tabel 1. Distribusi frekuensi pasien Tuberkulosis berdasarkan jenis kelamin

\begin{tabular}{lll}
\hline Jenis Kelamin & Jumlah & Persentase \\
\hline Laki-Laki & 36 & $67,92 \%$ \\
Perempuan & 17 & $32,07 \%$ \\
\hline Total & 53 & $100 \%$ \\
\hline
\end{tabular}

Sumber:Rekam Medik RS Ibnu Sina Januari-Desember 2017 diolah MS Excel 2016

Tabel 2. Distribusi frekuensi pasien Tuberkulosis berdasarkan IMT

\begin{tabular}{lll}
\hline IMT & Frekuensi & Persentase \\
\hline Underweight & 35 & $66,03 \%$ \\
Normal & 17 & $32,07 \%$ \\
Overweight & 1 & $1,88 \%$ \\
\hline Total & 53 & $100 \%$ \\
\hline
\end{tabular}

Sumber:Rekam Medik RS Ibnu Sina Januari-Desember 2017 diolah MS Excel 2016

Tabel 3. Distribusi frekuensi pasien Tuberkulosis berdasarkan Umur

\begin{tabular}{lll}
\hline Umur & Frekuensi & Persentase \\
\hline 1-25 Tahun & 11 & $20,75 \%$ \\
$26-50$ Tahun & 17 & $32,07 \%$ \\
$>50$ Tahun & 25 & $47,16 \%$ \\
\hline Total & 53 & $100 \%$ \\
\hline
\end{tabular}

Sumber:Rekam Medik RS Ibnu Sina Januari-Desember 2017 diolah MS Excel 2016

Tabel 4. Distribusi frekuensi pasien Tuberkulosis berdasarkan Pekerjaan

\begin{tabular}{lll}
\hline Pekerjaan & Frekuensi & Persentase \\
\hline Karyawan Swasta & 7 & $13,20 \%$ \\
Wiraswasta & 5 & $9,43 \%$ \\
Buruh & 8 & $15,09 \%$ \\
IRT & 10 & $18,86 \%$ \\
Mahasiswa & 4 & $7,54 \%$ \\
PNS & 4 & $7,54 \%$ \\
Pedagang & 2 & $3,77 \%$ \\
TNI & 1 & $1,88 \%$ \\
Pensiunan & 2 & $3.77 \%$ \\
Tidak bekerja & 10 & $18,86 \%$ \\
\hline Total & 53 & $100 \%$ \\
\hline Sumber:Rekam Medik RS Ibnu Sina Januari-Desember 2017 diolah MS Excel 2016
\end{tabular}

